\title{
Review
}

\section{Representing justice: Invention, controversy and rights in city-states and democratic courtrooms}

\author{
Judith Resnik and Dennis Curtis \\ Yale University Press, New Haven, CT, 2011, xviii + 720 pp., £50.00/\$75.00 \\ ISBN: 978-0300110968
}

Contemporary Political Theory (2013) 12, e10-e13. doi:10.1057/cpt.2012.19

'Monumental' is the best way to describe Judith Resnik and Dennis Curtis's tome, Representing Justice, which features over 400 pages of commentary, 200 pages of notes and 250 images depicting the rich, complex and often fraught relationship between art and adjudication. Although the authors weave a dazzling tapestry of art history, political philosophy and legal scholarship, this is by no means a purely academic work. The reader is invited to join the authors through their inquisitive meanderings through cities, palaces, museums and courtrooms - as well as some unexpected spaces - to uncover how cultures and societies have translated ideas about justice into art.

As ancient political philosophers knew well, justice is an elusive virtue. Nowhere is that elusiveness better captured than in Aristotle's definition of justice as 'treating likes alike', ${ }^{1}$ a maxim that, as Aristotle acknowledges, reveals next to nothing about how to act in a given instance unless one already knows what is like. In other words, to discern like from unlike, one must already be a just person. So how do adjudicators set about being just? This is where artistic representation plays a vital role: societies have sought to define this nebulous virtue through visual allegories and metaphors, to say nothing of the libraries of tales and parables that they have told in order to imbue the abstraction of justice with meaning. Pace Plato, Representing Justice is not merely about second-order reflections of justice, but about the first-order constitution of the very meaning of justice through art.

Of all the book's imagery, ranging from the noble to the shockingly cruel, the unquestionable protagonist is Lady Justice in her many guises. She is the totem onto which Western societies have projected their concerns about power and legitimacy. Her omnipresence is a visual reminder of John Rawls's (1971, p. 3) famous dictum that 'justice is the first virtue of social institutions', which hovers over the book like an invisible epigram, not because the authors affirm it, but to the contrary, because they mean to question the primacy of justice. In earlier imagery, the authors point out that Lady Justice did not stand alone,

(C) 2013 Macmillan Publishers Ltd. 1470-8914 Contemporary Political Theory Vol. 12, 4, e10-e13 www.palgrave-journals.com/cpt/ 
but was flanked by temperance, prudence, fortitude and other classical virtues. With her sisters relegated to antiquity, however, justice has come to be treated as a self-sufficient ideal, a secularized cardinal virtue for the moderns. How, the authors ask, did justice come to be so central? Why are all contemporary controversies about public power framed and comprehended in terms of justice rather than any of the other virtues?

Allegories of justice over the centuries, such as early modern images of judges being flayed alive for contravening the sovereign's orders, illuminate the symbolic primacy of justice, which the authors argue derives from the 'neverending need to legitimate state violence' (p. 12). As the state's capacity to exert force has increased, so too has its need to present its actions as virtuous. That said, when justice is identified with the interests of the powerful, as Thrasymachus would have it, its representations appear to serve no purpose other than consecrating that rule. The result is a profound tension that makes the book such a riveting read: justice ought to be on the side of the vulnerable, but it is often used to bolster the state's claim to power and to elicit consent from its reluctant subjects. And yet, taken to its limit, this cynical reading threatens to undermine the purpose of the book: if official representations of justice are self-serving, what reason do we have for taking them seriously? Iconography that is commissioned, sanctioned and deployed by the state and its organs may claim to represent justice, the cynic might say, but all it represents is power.

In fact, the most poignant instances of this book are those where power and justice part ways. For example, the authors chronicle controversies that have raged over publicly commissioned artworks in US courtrooms invoking racial, colonial or gendered injustices. Various works designed for American courthouses have been attacked for depicting justice in the 'wrong' way, as a 'mulatto', 'Communist', indecent or 'clowning' figure (pp. 106-124). Just as early modern courthouse art reminded judges to be docile and obedient to the will of their sovereign with gory depictions of judges with their hands lopped off, the handiwork of the insufficiently deferential court artist is subjected to a comparably primitive sort of censorship.

Precisely because the imagery of justice has been deployed to sanction power, the handful of images that suggest that justice might sometimes require defying the law are powerful and haunting. The South African Constitutional Court has been built on the site of an apartheid-era prison, and preserves the marks of decades of abuse perpetrated within its confines. The murals that adorn the Mexican Supreme Court provide equally visceral reminders of egregious and arbitrary uses of state power. Rafael Cauduro's arresting images break with the usual piety of courthouse art in which justice is represented as the guiding light of a benevolent state, and instead depict acts of torture, rape and mass murder carried out by agents of the state. 
Far from simply being a paean to justice-themed art, the book uses the plasticity of justice as a visual symbol to critique our single-minded focus on justice as a 'first virtue'. 'As the only attribute of government', Resnik and Curtis write, justice 'becomes reduced to power rather than working as one of a set of principles and obligations that constitute good governance' (p. 17). By fixing our gaze too tightly on justice, we have lost sight of the other virtues required of institutions that govern complex, diverse societies that aspire to democratic self-rule. Normative discourse in general, and adjudication in particular, they argue, must be guided by a richer repertoire of values, principles and 'virtues' than those captured by the endlessly reproduced symbols of swords, scales and blindfolds.

If the artistic imagery of justice is highly salient for understanding the legitimation and reproduction of public power, democratic or otherwise, the disappearance of this tradition of visual representation is equally telling. In late capitalist societies permeated by the exigencies of efficient administration, the authors argue, courts as old-fashioned sites of democratic praxis are becoming obsolete. Despite their traditional construal as non-majoritarian or even antidemocratic bodies, the authors argue, courts fulfill a crucial role in democratic self-government insofar as they provide a site where norms are negotiated, contested and shaped by those who are bound by them. By contrast, chapter 14 highlights the slow and insidious migration of adjudicative functions toward private arbitral institutions and administrative agencies impervious to the standards of publicity and accountability required of courts in democratic systems. The 'outsourcing' of dispute resolution to private or quasi-private fora serves to 'cut off the communicative possibilities' that courts employ in resolving disputes (p. 336).

Interestingly, where adjudication is reduced to a bureaucratic function, it eschews art and iconography altogether. Because they are not considered a part of contemporary democratic politics, 'outsourced' forms of adjudication are not subject to the same pressing need for public legitimation and consequently do not resort to redeeming imagery of their own. It is telling that the only piece of iconography the authors are able to muster in relation to private arbitration is the monochromatic copy of their own cell phone contract, which obliges them to waive their rights to sue the service provider in court (p. 319). Similarly, we witness the grand architecture of courts being eschewed in favor of multipurpose 'law enforcement centers' that fulfill a range of bureaucratic functions. The contrast between the visual grandeur of traditional courts and the invisibility of new forms of adjudication underlines the fact that the latter are much less accessible to the public even though they 'decide the rights and obligations of hundreds of thousands of individuals' (p. 318). Even in the case of administrative hearings that "[a]s a practical matter, everyone has the "right" to attend', the authors point out that the proceedings are physically difficult to locate (p. 318). 
One is reminded of Franz Kafka's novella, The Trial, in which an ordinary citizen is arrested under undisclosed criminal charges filed by a court whose physical location is elusive, and whose bizarre workings the accused cannot hope to grasp.

Without the aid of fictional exaggeration, the authors show that the shift toward arbitration, bargaining, negotiation and alternative dispute resolution is justified in the name of diminishing the caseload of courts, easing the financial strain traditional court proceedings place on public coffers and resolving disputes speedily so that business can be resumed. Does this mean that we are moving from a world in which 'justice' was the first virtue of adjudicative institutions, to one in which 'efficiency' fills the same role? Critics may ask whether the two main lines of critique in the book - of our overreliance on the idea of justice on the one hand, and of the gradual obsolescence of the public ideal of justice as a result of alternative dispute resolution mechanisms on the other - pull in separate directions. Despite their worries about justice's ultimate inadequacy, the authors' tone is nostalgic and reverential. We might just walk by a courthouse one of these days to see Lady Justice replaced by a new symbol, perhaps a figure in classic drapery, sporting spectacles instead of a blindfold, clutching a calculator in one hand and a wad of cash in the other.

\section{Note}

1 Although it is at best a rough translation of a complex point, this phrase is commonly used as shorthand for the argument Aristotle makes in the Nicomachean Ethics at Bk. V, Chapter 3, 1131a10-35. Also see Politics, Bk. III, Chapter 9, 1280a10-25.

\section{Reference}

Rawls, J. (1971) A Theory of Justice. Cambridge, MA: Harvard University Press.

Turkuler Isiksel

Columbia University, New York 10027, USA

(C) 2013 Macmillan Publishers Ltd. 1470-8914 Contemporary Political Theory Vol. 12, 4, e10-e13 e13 